\title{
㠃 OPERATIONS RESEARCH IN THE FUNCTION OF OPTIMAL DECISION-MAKING, WITH THE CASE ANALYSIS ON BEGINNING OF THE FIRST WORLD WAR IN 1914 BY AUSTRO-HUNGARIAN ATTACK ON SERBIA*
}

Spasoje Mučibabić University of Defense, Military Academy, Belgrade, Serbia

The paper is interdisciplinary in character and makes the synthesis of Operations Research Methods: Mathematical-Statistical Methods and Military-Strategic Analysis. The data are principally obtained from international and national archives, whereby there is a reasonable suspicion that all international archives are not yet open. The aim of the paper is to get to the truth concerning the causes and the role of Serbia in the onset of the First World War, by using reliable and comprehensive relevant sources of data through combined scientific methods of Operation Research and statistics, and Historic methods.

Key words: Serbia, Austro-Hungary, First World War, Sarajevo

\section{Introduction}

Decision making is the beginning of war. At the strategic level can be mathematically described by the following five elements [14]:

$\mathrm{O}=\mathrm{f}(\mathrm{A}, \mathrm{S}, \mathrm{P} . \mathrm{X}, \mathrm{k})$,

where: $A=\left\{a_{i}\right\}$ - set of alternatives of the decision-maker; $S=\left\{s_{j}\right\}-$ set of alternatives of the opponent; $P$ - mapping the decision into outcome; $X$ - outcome, payment of the decision and $k$ utility function.

Basic factors of the war are explained: people, material-technical factor, finance and information, space and time and it is given their mutual relationship, clearly showing the multiple superiority of Austro-Hungary over Serbia. Per each factor are given basic values and characteristics that clearly show the multiple superiority of Austro-Hungary over Serbia and is confirmed the hypothesis that Serbia could not make a rational decision to begin a war against Austro-Hungary. Military-Strategic Analysis was carried out through the following contents: 1) Crown Prince Franz Ferdinand (18 ${ }^{\text {th }}$ December $1863-28^{\text {th }}$ June 1914) was the Chief Inspector of the Armed Forces of the AustroHungary, i.e. the military officer; 2) With a plan he attended the maneuvers of the $15^{\text {th }}$ and $16^{\text {th }}$ Anny Corps, which were carried out on the territory of Bosnia, according to the

* First made for International Conference in India; first published in Mathematical Modeling, Optimization and Information Technology, ISBN: 978-3-659-71422-1, LAMBERT Academic Publishers, 2015. 
Operations research in the function of optimal decision-making...

developed plans of attack on Serbia; 3) On the territory of Bosnia and Herzegovina were located respective Austro-Hungarian forces (two corps, three infantry divisions, eleven brigades); 4) It is shown the relationship of the official authorities of Serbia and participants in the Sarajevo assassination [1]

In conclusion, it was pointed out the following: 1) Pre-research shows that all the archives are still not open from the military point of view; 2) It is proposed scientific and team research, with mandatory involvement of Serbian and Austrian representatives, in order to perceive this event comprehensively, objectively and independently of the actual politics and thus prevent unfounded blaming of Serbs; 3) Concretely, it was shown the possibility of applying Operations Research (combined Mathematical-Statistical Methods and Military- Strategic Analysis) in proving the truth about events in the past, as well as the prevention of unfounded and counterfeited representation of events, where scientists of this generation have a special responsibility $[12,13]$.

\section{Decision making process - the first step of problem solving}

Every system which aspires to achieve a goal must operate in planned and organized manner. This is provided by effective decision-making, present in all processes which results in decisions [14].

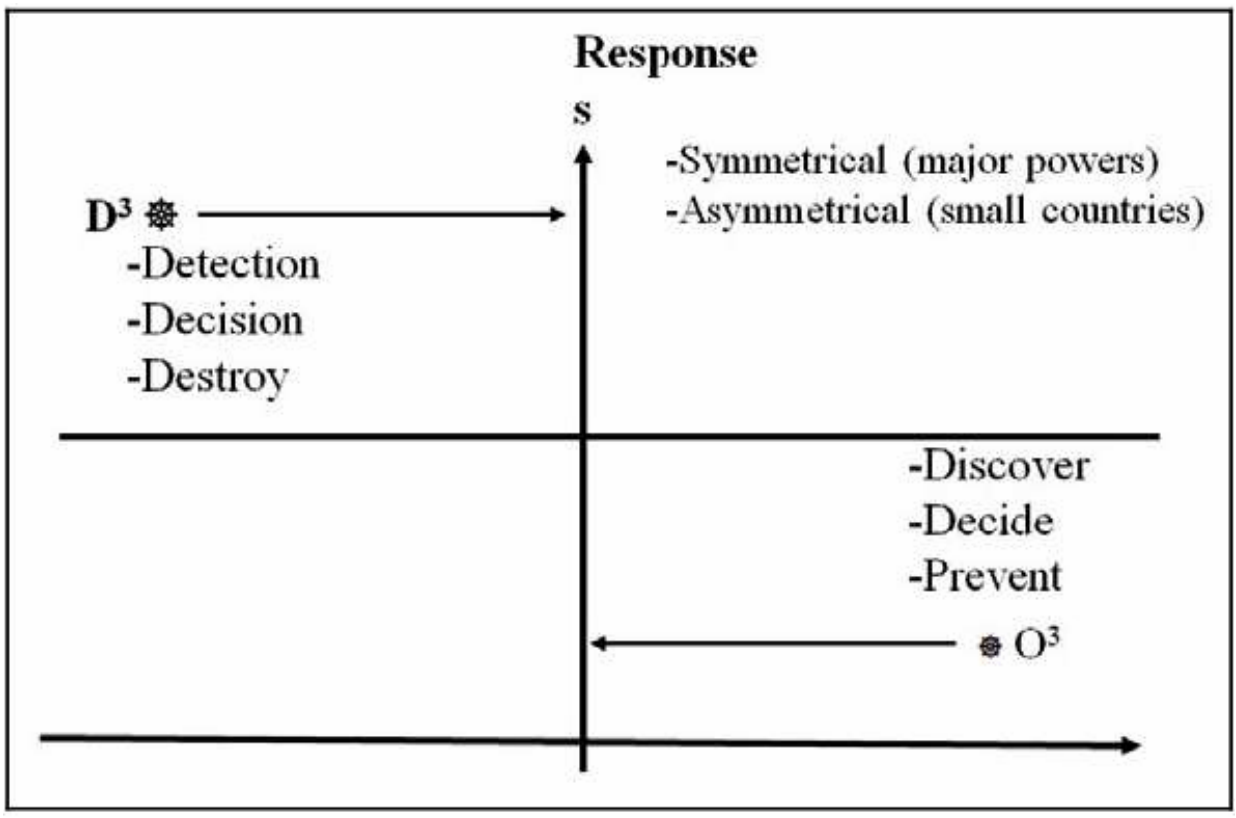

Fig. 1 - Serbia's warfare strategy in the First World War 


\section{Factors of armed struggle}

Following factors affect on course and outcome of armed struggle (Fig. 2): human resources, physical resources, space, time and information. Factors armed struggle are interdependent, interconnected, conditioned and determined at the level of the conflicting parties. In particular spatial and temporal conditions of the quality and quantity of human and material resources and information have crucial influence to the course and outcome of armed struggle.

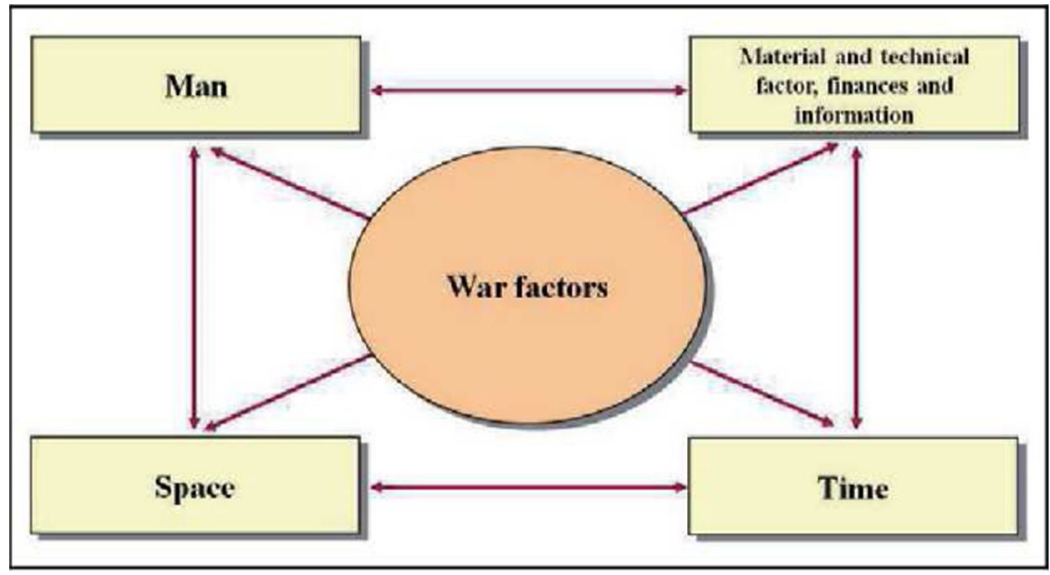

Fig. 2 - War factors

Human resources comprise the demographic potential conflicting parties capable and trained for military engagement. They have crucial influence the course and outcome of armed conflict. Human life is inviolable value in combat [7],

Material resources include natural, economic, financial, energy and information potential of conflicting parties engaged for military needs. Providing material resources for military needs have a strategic importance for the realization missions and tasks of Serbian Armed Forces. The space includes land, aquatorium and airspace where operations are performed, and its size and quality significantly influence the course and outcome of armed conflict. Skillfully use of space, with the timely preparation and planning, enables successfully carry out combat operations. Tendencies in the execution the armed struggle indicate that the operations performed by military forces from selected baseline, but without clearly defined characteristics of spatial coordination and division in front, background and depth. Time manifests itself as: historical period, duration, period of day and year and meteorological phenomena. Armed struggle is characterized by accelerating processes and activities, and because of that time became one of the decisive factors of armed struggle. Information as factor of armed struggle, expressing the availability of knowledge and information necessary for the efficient leadership at all levels, thus reducing the uncertainty in military activities. The quality and timeliness of information are requirements that each level of command trying to provide [2]. 


\section{Quantitative analysis of factors of war}

GNP in 1913 was 35.9 times higher in Austria-Hungary than Serbia.

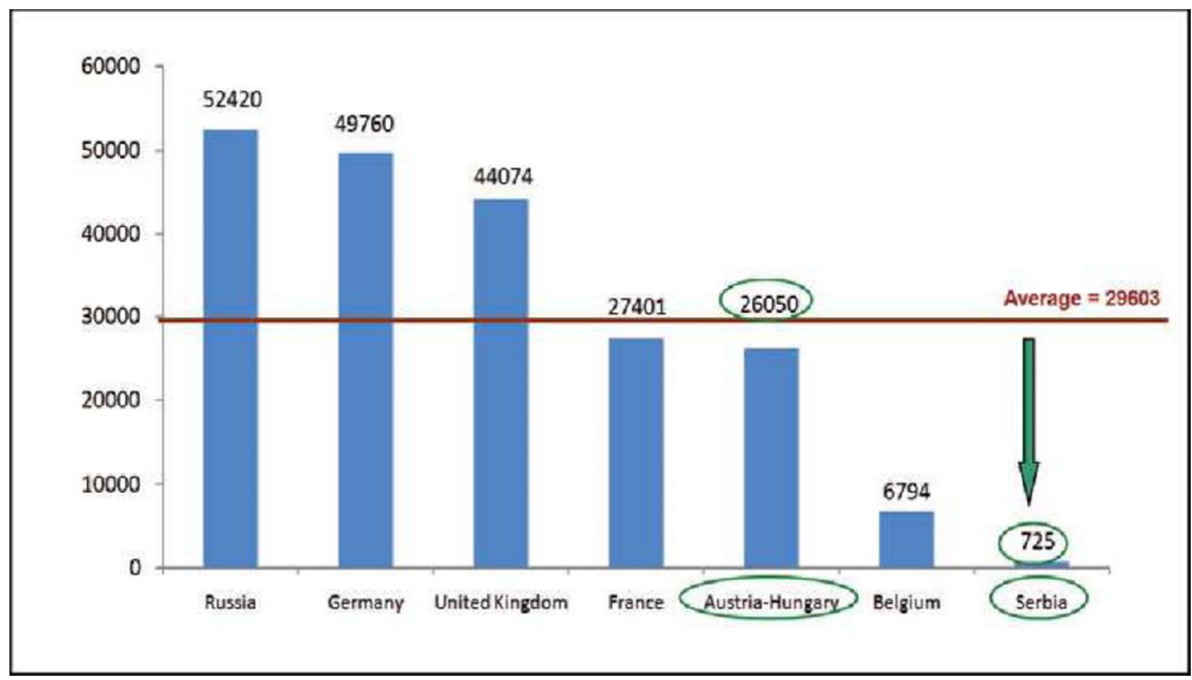

Fig. 3 - GNP (PPP) in 1913 (in millions of 1960 US dollars)

GNP per capita in 1913 was 2.8 times higher in Austria-Hungary than Serbia.

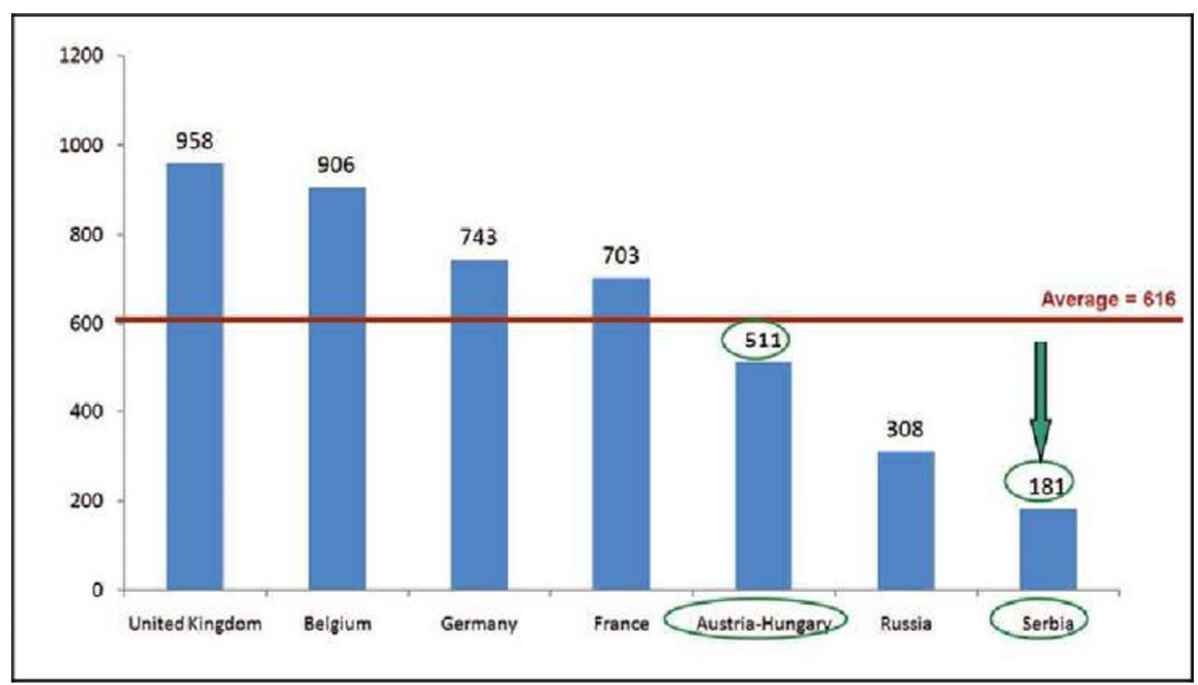

Fig. 4 - GNP (PPP) per capita in 1913 (in 1960 US dollars) 
Population and area at the beginning of the First World War: Serbia - Austria -Hungary:

- Austria-Hungary had 12.75 times more population.

- Austria-Hungary had 7.6 times bigger area.

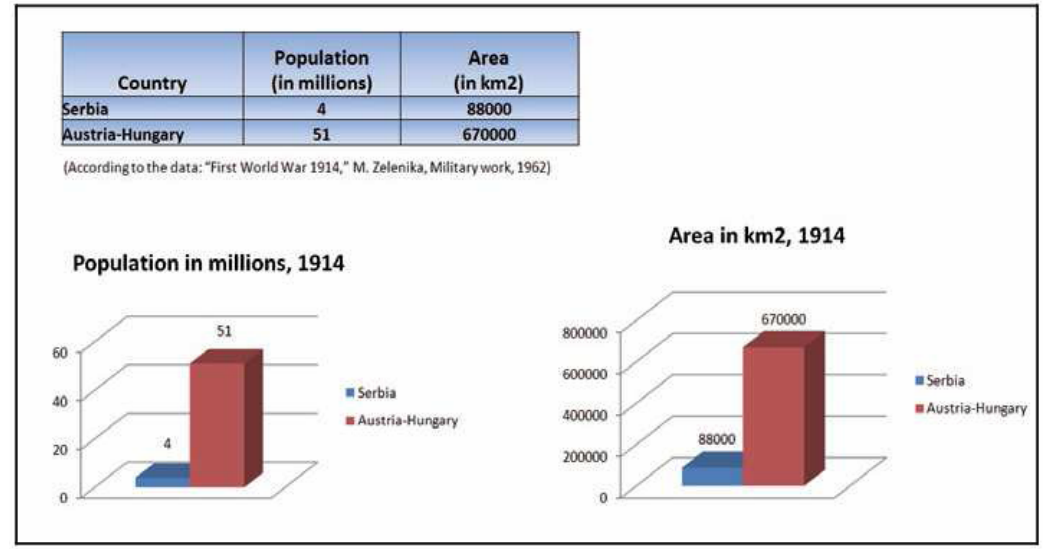

Fig. 5 - Population and area at the beginning of the First World War

Armed forces at the beginning of the First World War: Serbia - Austria - Hungary

- The ratio between the peace-time armed forces of Austria-Hungary and Serbia was 9:1.

- The ratio between the mobilization armed forces of Austria-Hungary and Serbia was 7.4:1.

- The ratio between the operational army of Austria-Hungary and Serbia was 7.2:1.

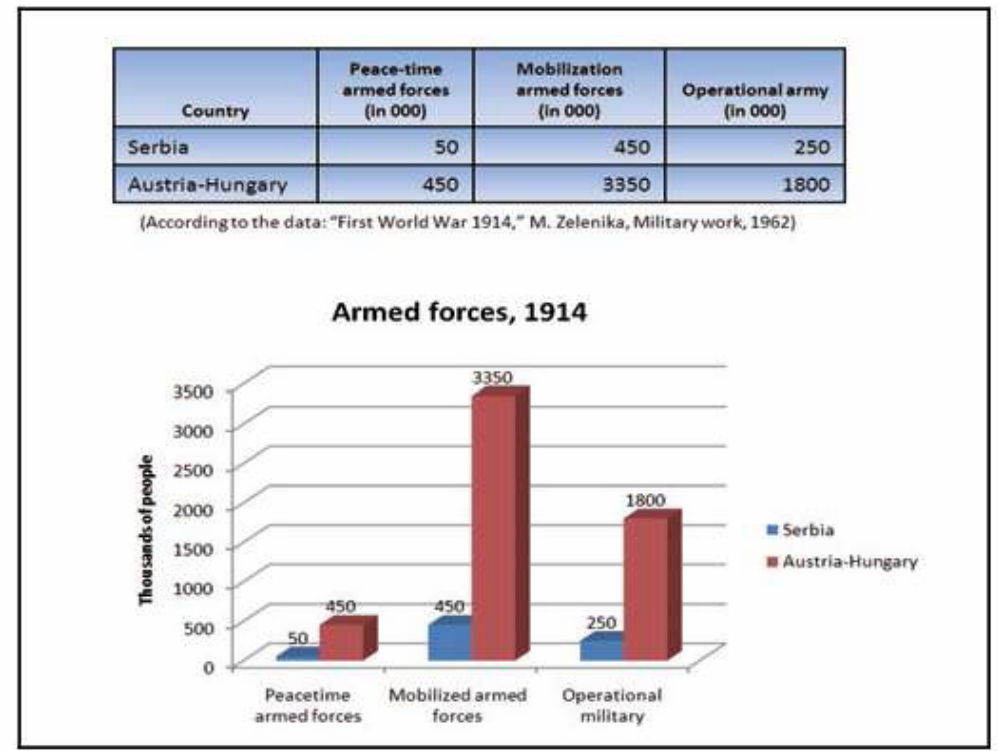

Fig. 6 - Armed forces at the beginning of the First World War 
Operations research in the function of optimal decision-making...

Relative share of the mobilized population of Serbia was almost twice as big as the relative share of the mobilized population of Austria-Hungary.

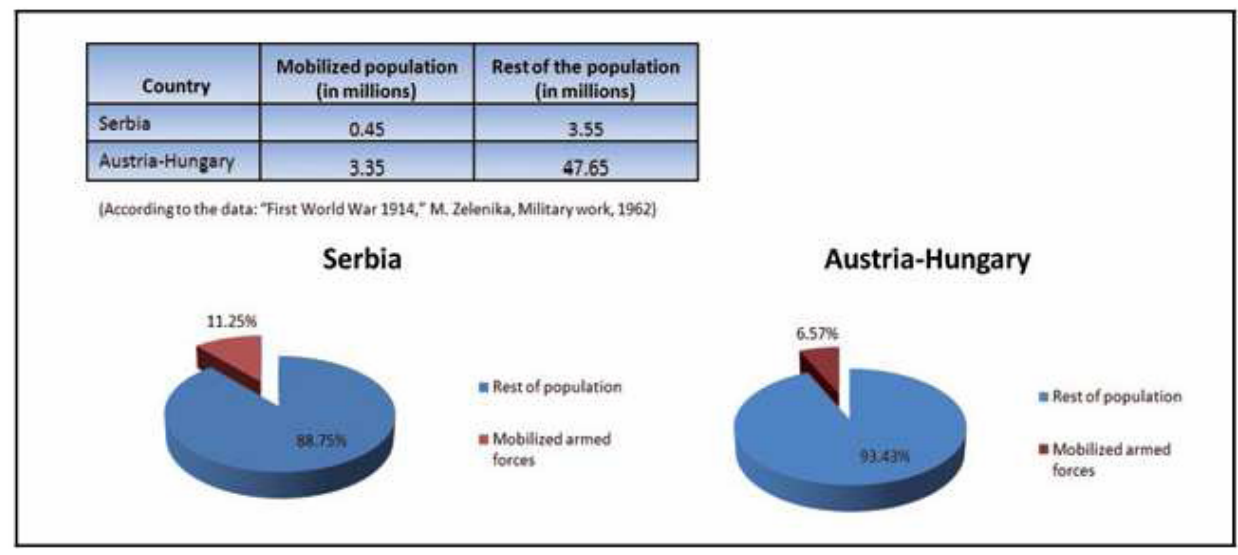

Fig. 7 - Population and area at the beginning of the First World War

\section{A brief historical analysis of the beginning of war}

"The battle between the Slavs and the Germanics cannot be avoided. It is bound to happen. When? It is to be seen... The Slavs were not born to rule, but to be servants and they must be made aware of this". Sarajevo assassination on $28^{\text {th }}$ June, 1914 was carried out against the Austria-Hungarian heir to the throne Franz Ferdinand in Sarajevo - Bosnia and Herzegovina (B\&H) [1].

As a matter of example, when discussing this topic, the American President Woodrow Wilson asked: "What are Austria-Hungary and Franz Ferdinand doing in Bosnia?" Wilson maintained that "these were Serbian lands and they (AustriaHungarians) had nothing to do there". The assassination was carried out by a group of 8 members of all three nations from the then B\&H (Serbs, Croats and Muslims) who were members of the Mlada Bosna organization.

Mlada Bosna was a youth liberation association which grew into a movement and whose members came from all three nations that lived in $\mathrm{B} \& \mathrm{H}$, without organizational structure, and with no financial support from the background. In the then Europe there were similar organizations in Italy, Germany, Romania. 


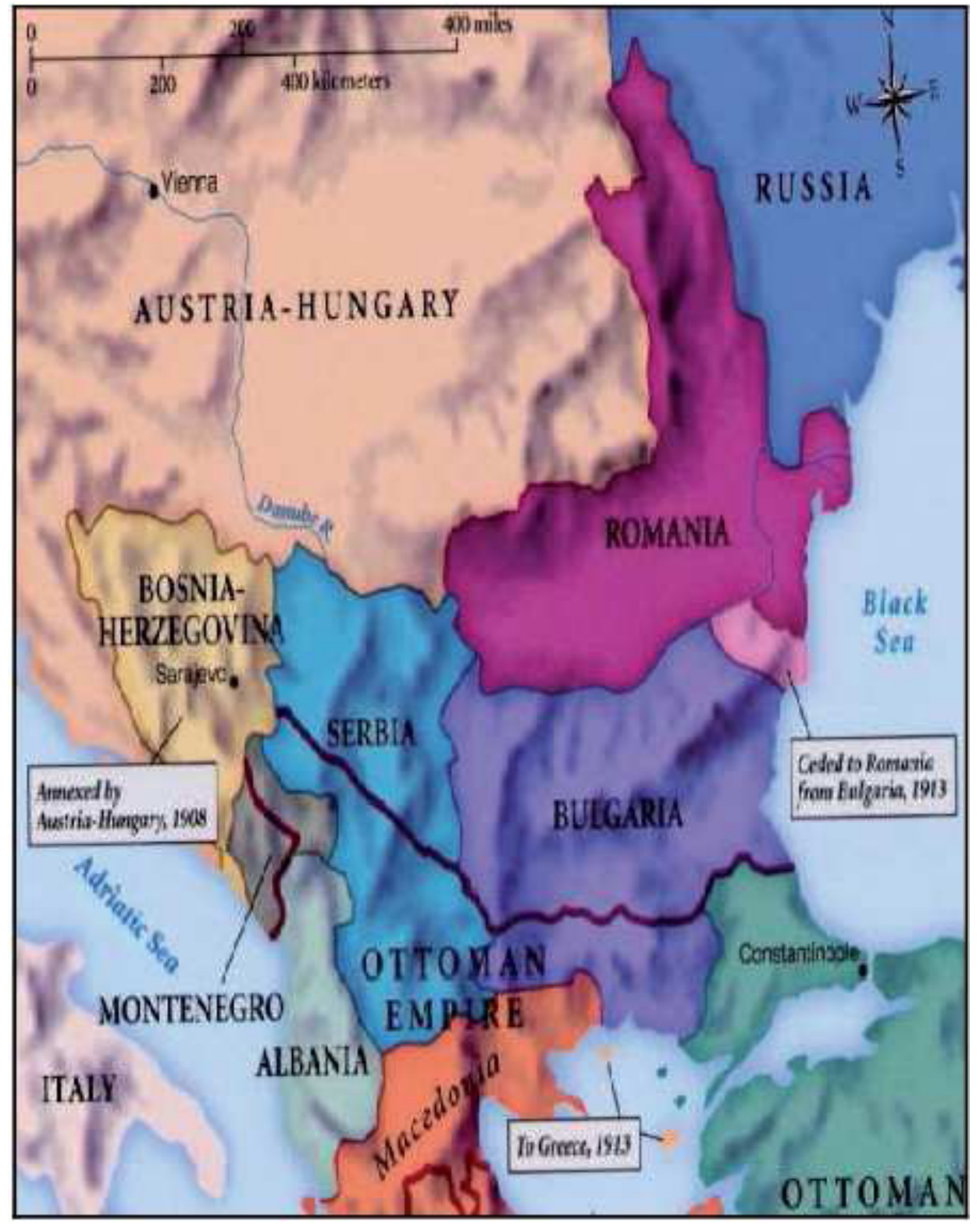

Fig. 8 - Direction of the operations - main forces are directed towards Serbia 
Before the Sarajevo assassination, in the period from 1902 to 1914, the police was on an alert a dozen times, because they received information regarding the preparation of an assassination of Franz Ferdinand.

According to reliable sources, there were three attempts (1902 - Italy, 1906 - Slovenia, where a wagon in the heir to the throne's train was blown up on $14^{\text {th }}$ August during the military maneuvers near Moravska Ostrava). During this period, assassinations of tyrants were frequent in Europe. Many people in the monarchy considered the heir to the throne a tyrant, as did the members of Mlada Bosna [3, 4].

During the visit of Archduke Franz Ferdinand to the city of Sarajevo, an eight-member group of the Mlada Bosna organization spread along the route of the heir to the throne. The first attempt at assassination by Nedeljko Čabrinović failed. The second attempt by under-age Gavrilo Princip succeeded [5, 10].

Gavrilo Princip was born in Veliki Obljaj, Bosnia and Herzegovina, in 1894 and passed away at the prison in Terezin, Czechoslovakia, in 1918. The shown photograph was taken over from the investigative judge Pfeffer after 1938 [3].

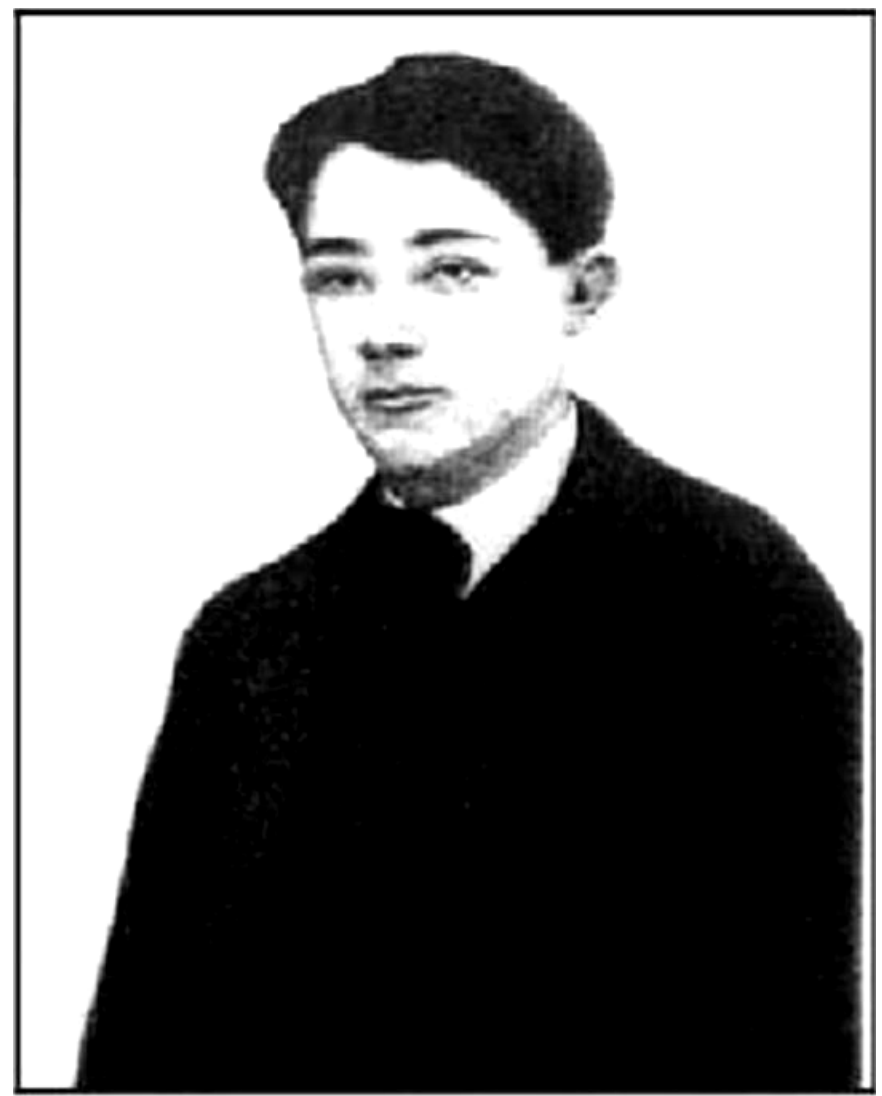

Fig. 9 - Gavrilo Princip 
The photo was first shown at the Scientific Meeting of historians held in Gacko in 2013.

"Gavrilo Princip, who fired the shot, did so on account of being imbued with the ideals of nationalism as a sign of protest against the oppression of the Southem Slavs". ${ }^{1}$ The most complete and most objective appraisal of the Sarajevo assassination given by the investigative judge engaged for this process.

"Although the Great War found me still conducting the investigation, I was convinced then, as I am now, that the Sarajevo assassination did not cause the war, but rather that it was only the torch that enflamed a complex pyre of intertwined interests".

"The security measures on the day of the assassination were quite insufficient and the procedure after the first attempted assassination imprudent to the very end. By deciding that the heir to the throne Ferdinand should visit Sarajevo right on the biggest national holiday of the Serbs, Vidovdan, the authorities in the Monarchy provided Princip and Čabrinović with the final impetus to carry out the act".

Mlada Bosna was youth, multi-national, liberation association similar to others in Europe which fought against the oppression of the Southern Slavs. Gavrilo Princip, a juvenile, opted for assassination in his fight against the oppression of the Southern Slavs, since at the time it was it was the only method of fighting the aggressors in Europe [1, 6, 10]. "Hetzendorf (Chief of General Staff of Austria - Hungary) first proposed a preventive war against Serbia in 1906, then repeated this in 1908-1909, then again in 1912-1913, in October 1913 and in May 1914. Between 1st January, 1913 and 1st January 1914, he proposed war against Serbia 25 times. He had full support of Germany".

"Although Mr. Wizner already on $13^{\text {th }}$ July, 1914 reported back to Vienna that the results of the investigation did not prove any guilt on the part of the Serbian government, the Vienna and Pest diplomats blamed the Serbian government nonetheless, as if it was its task to safeguard the Austria-Hungarian heir to the throne". 3

\section{Some indicators of the consequences of war}

However, human losses of Serbia in the First World War were far greater than any of the warring parties and amounted to as much as $28 \%$ of the total the population of Serbia in 1914 . $^{4}$

\footnotetext{
1 "Investigation in the Sarajevo assassination," L. Pfeffer, New Europe, Zagreb, 1938.

${ }^{2}$ Military historian New Strachan, 2001.

3 "Investigation in the Sarajevo assassination." L. Pfeffer, New Europe, Zagreb, 1938.

${ }^{4}$ According to the data: „Epilogue the First World War in numbers ${ }^{* 4}$, Alexander Nedok, Milisav Sekulić, a special edition of the journal "Military Medical Review," no. 65 („Serbian army medical corps from 1917 to 1918").
} 
Operations research in the function of optimal decision-making...

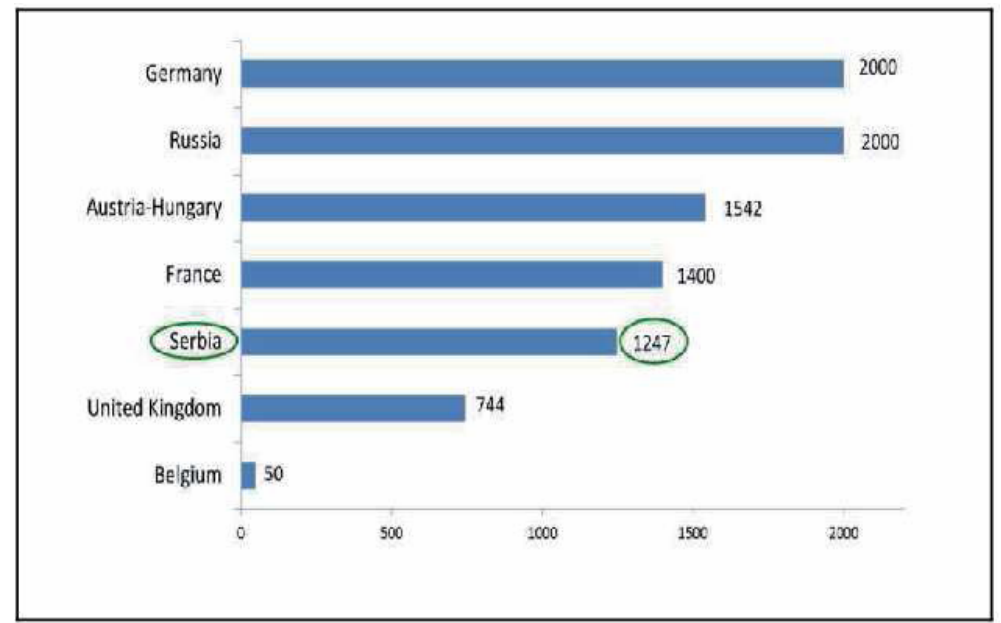

Fig. 10 - Victims of the First World War (in thousands)

According to the data: "Epilogue the First World War in numbers", Alexander Nedok, Milisav Sekulić, a special edition of the journal "Military Medical Review," no. 65 („Serbian army medical corps from 1917 to 1918") relative share of the victims in the population was as follows:

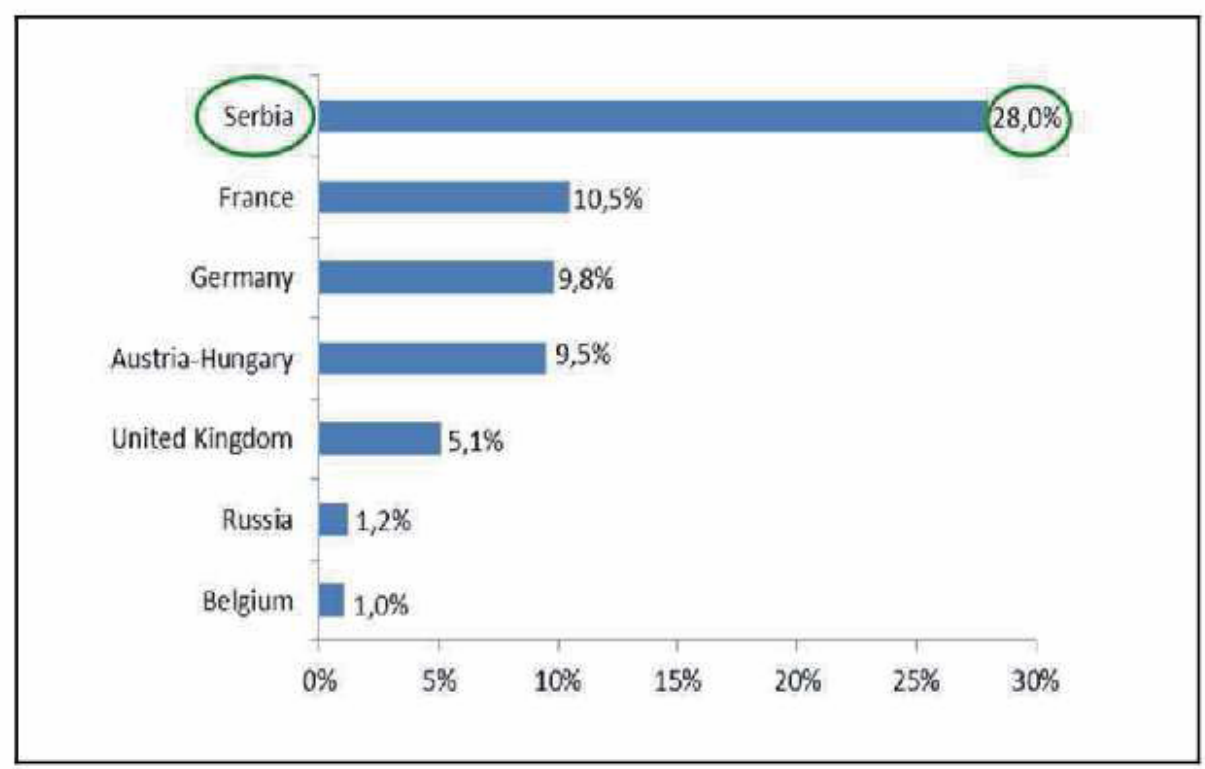

Fig.11 - Relative share of the victims in the population 
According to the data: „Epilogue the First World War in numbers“, Alexander Nedok, Milisav Sekulić, a special edition of the journal "Military Medical Review," no. 65 („Serbian army medical corps from 1917 to 1918") "First World War 1914,” M. Zelenika, Military work, 1962.

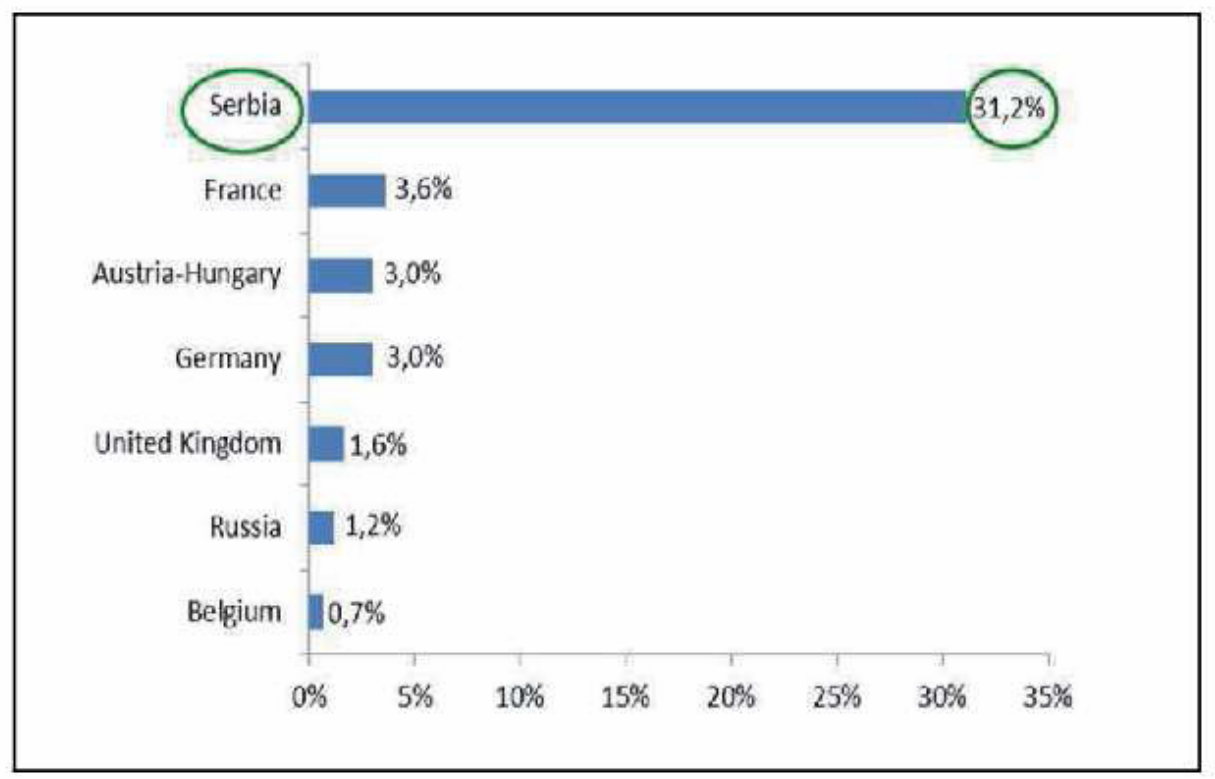

Fig. 12 - Relative share of the victims in the population

Victims of the First World War - relative share of civilian losses of Serbia is $67.74 \%$.

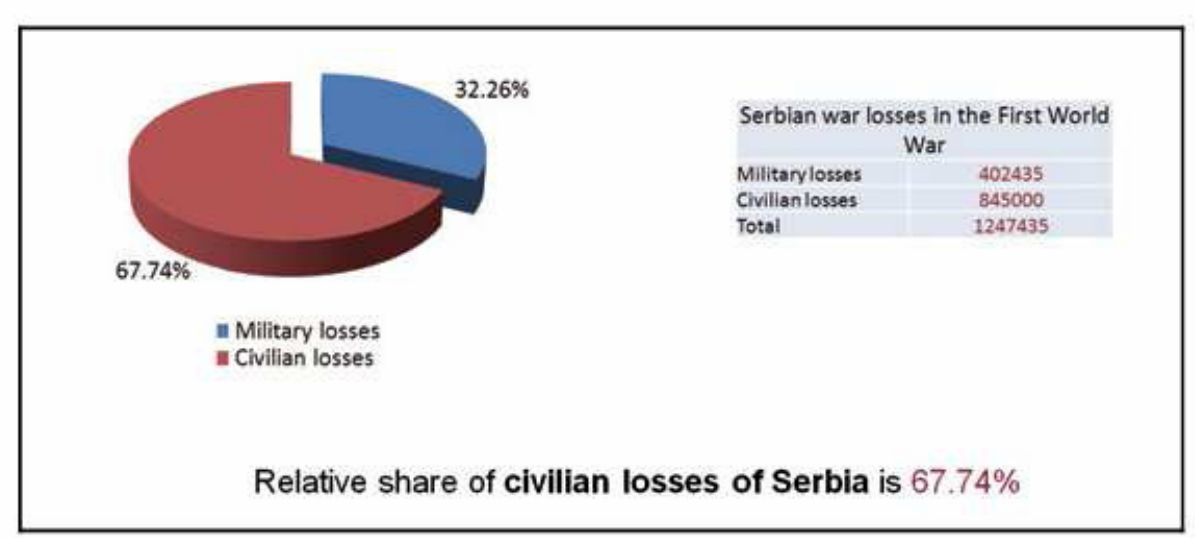

Fig. 13 - Victims of the First World War (in thousands) 
According to the data: "Demographic losses caused by Serbian wars of the $20^{\text {, }}$ century“, Dušan Vručinić, the Museum of Genocide Victims, Belgrade, 2007, Civilian losses, Serbia, World War I:

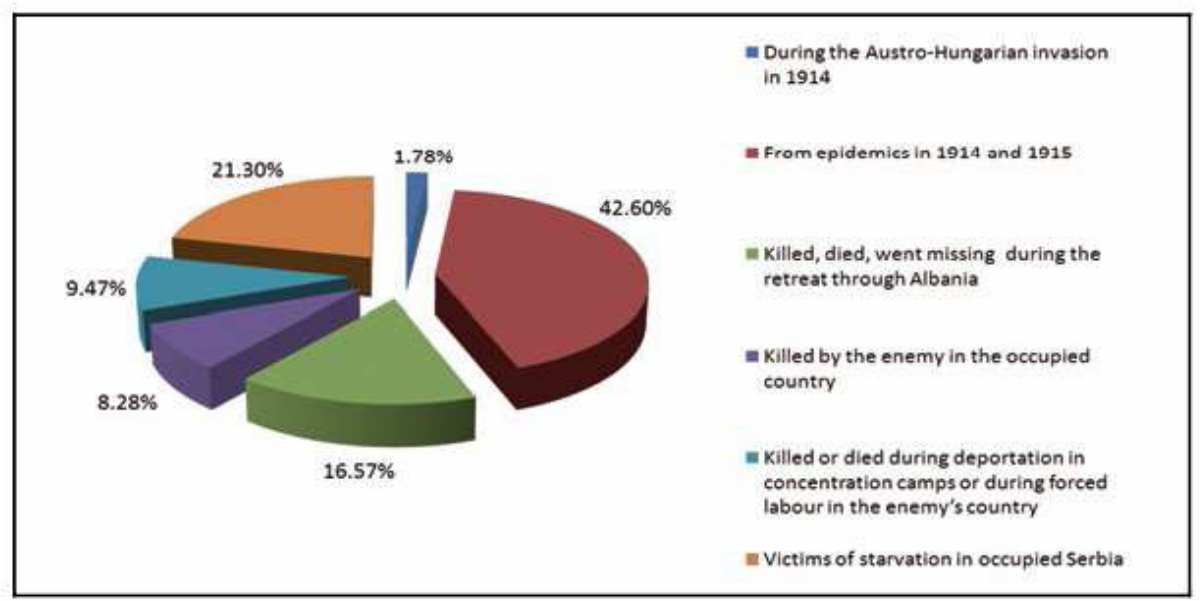

Fig.14 - Civilian losses, Serbia, World War I

According to the data: "Demographic losses caused by Serbian wars of the $20^{\text {th }}$ century", Dušan Vručinić, the Museum of Genocide Victims, Belgrade, 2007 "First World War 1914," M. Zelenika, Military work, 1962, of 450,000 mobilized armed forces there was 402,435 military losses.

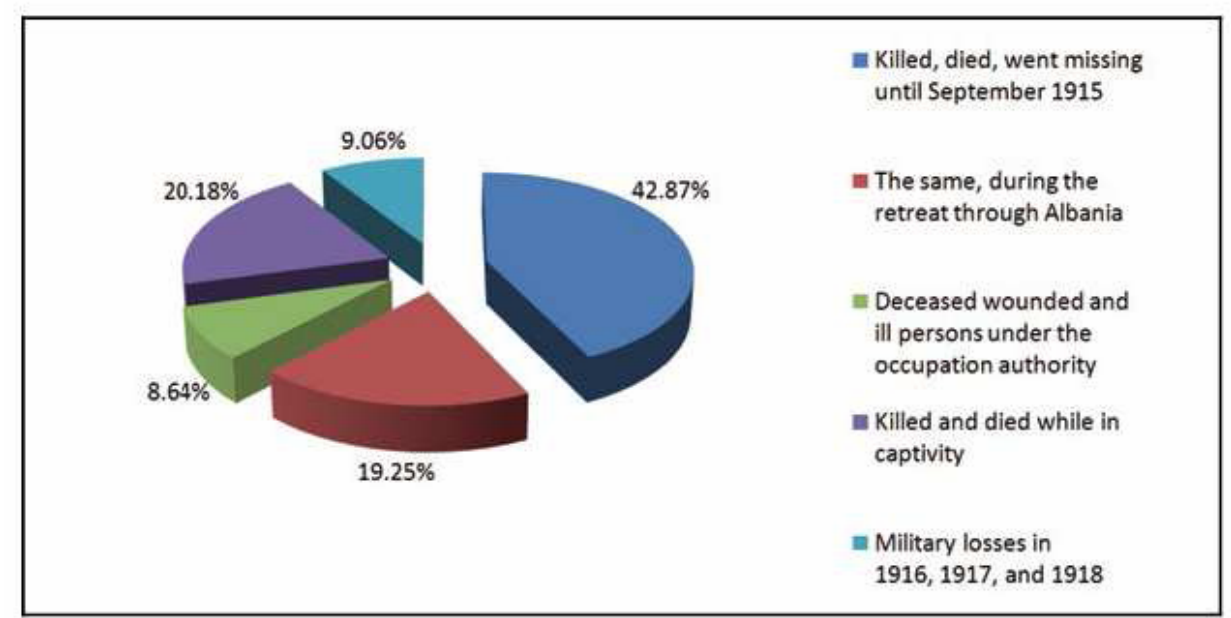

Fig. 15 - Military losses, Serbia, World War I 
According to the data: „Epilogue the First World War in numbers“, Alexander Nedok, Milisav Sekulić, a special edition of the journal "Military Medical Review," no. 65 („Serbian army medical corps from 1917 to 1918"), killed and died officers and soldiers during World War I:

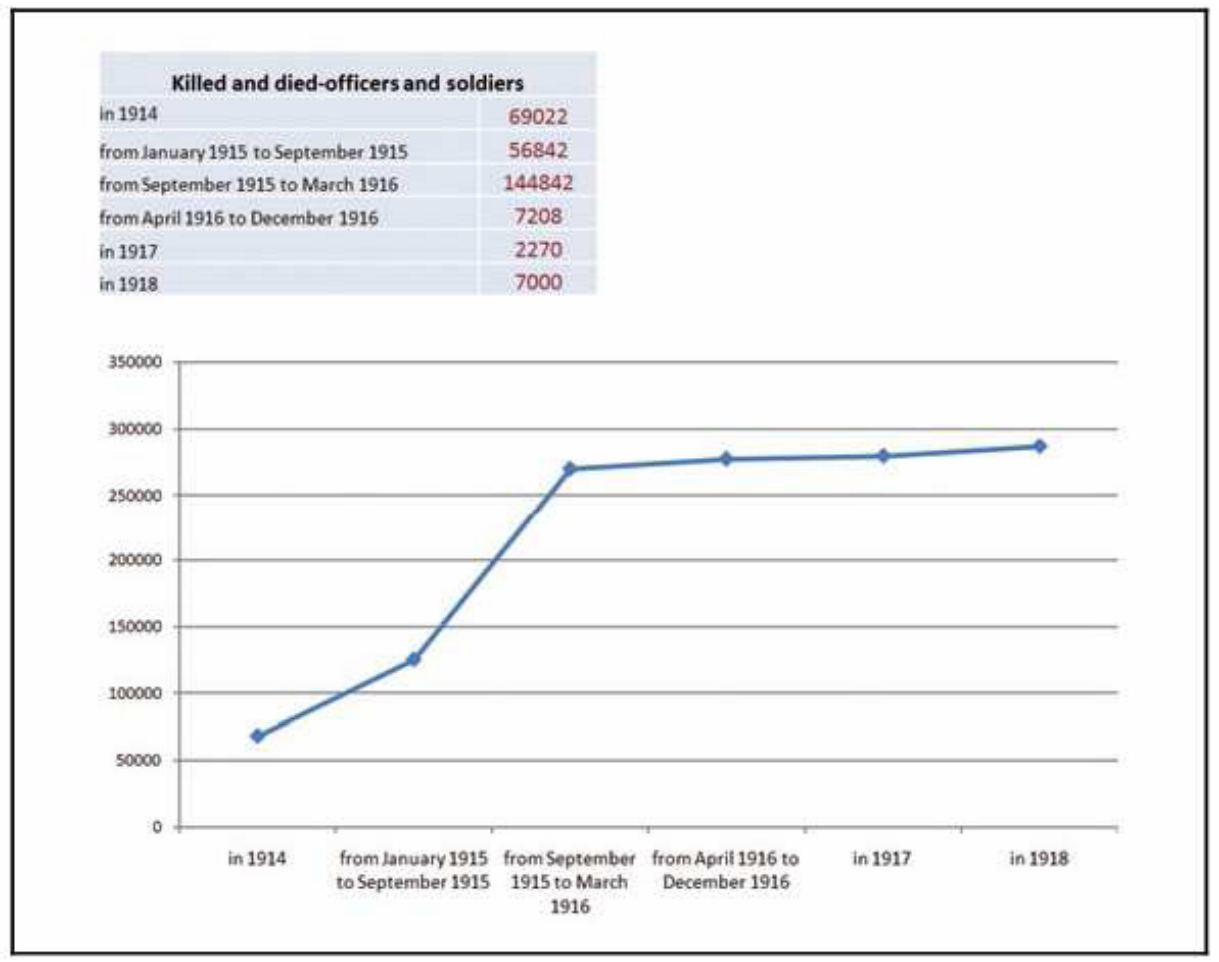

Fig. 16 - Killed and died officers and soldiers, World War I

The basic cause is the discrepancy in the ranking of the major powers and the division of the world.

$19^{\text {th }}$ century ranking:

$20^{\text {th }}$ century ranking:
1. United Kingdom
1. USA
2. France
2. Germany
3. USA
3. United Kingdom
4. Germany
4. France

Germany wants a new division in Asia, Africa and then in Europe as well. With the likeminded, Austria-Hungary, it signs the Agreement on the destruction of Serbia on 23rd October, 1913 (8 months before the Sarajevo assassination) [8, 11]. Today, the Operation Research and statistics methods are predominantly used for foretelling the future. In the paper, they were used for proving the truth about the past. 
Operations research in the function of optimal decision-making...

CONCLUSIONS: The paper shows that the only right way to the truth regarding the role of Serbia in the onset of the First World War is by using:

- Concrete evidence based on the relevant documents which are a source of data;

- Data from all possible sources - analyses must be conducted in unchanged conditions in relation to the events that have taken place;

- Multi-dimensional and comprehensive analysis models (demographic, technical, economic, spatial, time aspect, etc.).

- The precondition for the beginning of the First World War was the political decision of Germany.

- The Sarajevo assassination was carried out by under-age Gavrilo Princip, member of youth, multi-national, liberation association Mlada Bosna.

- The tyrant assassination method was a frequent phenomenon in Europe during that period.

- Serbia, worn out by the Balkan wars (1912-1913) needed a necessary recovery and not a new war.

- The official authorities of the Austria-Hungarian investigation did not find any evidence in July 1914 that the official Serbian Government was responsible for the Sarajevo assassination.

\section{References}

[1] Dedijer, V., Sarajevo 1914, Prosveta Beograd, 1966.

[2] Kuročkin, A., Metodika vojnonaučnog istraživanja (Prevod), VIZ Beograd, 1963.

[3] Pfeffer, L., Istraga u Sarajevskom atentatu, Nova Evropa Zagreb, 1938.

[4] Tomac. P., Prvi svetski rat 1914-1918, VIZ Beograd, 1973.

[5] Slijepčević, P., i dr., Napor Bosne i Hercegovine za oslobođenje i ujedinjenje, Sarajevo, 1929.

[6] Ćorović, V., Crna knjiga, Beograd-Sarajevo 1920.

[7] Pandurski puč u Nevesinju 1879. g, Godišnjak Istorijskog društva Bosne i Herccgovine, 1956. g.

[8] Vojna enciklopedija, tom prvi, Bcograd, 1970.

[9] Vojna enciklopedija, tom drugi, Beograd, 1970.

[10] Vojna enciklopedija, tom treći, Beograd, 1970.

[11] Vojna enciklopedija, tom šesti, Bcograd, 1970.

[12] Vojna enciklopedija, tom sedmi, Beograd, 1970.

[13] Opricović, S. and Tzeng, G.H., The Compromise solution by MCDM methods: A comparative analysis of VIKOR and TOPSIS", European Journal of Operational Research, br. 2/2004, str. 445-455.

[15] Mučibabić, S., Odlučivanje u konfliktnim situacijama, Vojna akademija, Beograd, 2003. 